\title{
Regional Economic Analysis on the Agglomeration Effect, Allocation Efficiency, and Regional Economy Growth
}

\author{
Rong Zhang and Li Jiang \\ Harbin University of Commerce Harbin, China \\ School of Marxism, Heilongjiang University of Science and Technology, 2468 Puyuan, Songbei \\ District, Harbin, China \\ zhangrongrose@163.com
}

Keywords: Allocation efficiency; Economic aggregation; Function priority zones

\begin{abstract}
The cooperation of regional factor and non-regional factor makes up the characteristic of economic aggregation. The externality of the economics bases on the regional factor and the spillover of the efficiency of cooperation is the foundation of the externality. Taking the theoretical analysis into consideration, the factor mobility and the cooperation of regional factor and non-regional factor are concerned with the regional economic growth. And furthermore, the goals of the development of the certain region is no longer the growth, but the scientific order coming out of the cooperation of two kinds of factors, which is also the final goals of the major function area theory.
\end{abstract}

\section{Introduction}

In the 21 st century, with the development of modern transportation and information technology, the world economy has the characteristics of global economic integration, not only for the economy's scale but also for the division of labor. However, if taking the regional agglomeration of the global economy into consideration, scholars are unable to explain such issue effectively, that is, why individuals and enterprises still choose to gather themselves in the big cities, since the empirical data has clearly shown that the producing and living costs in the large cities are much higher than that of small cities. Based on the new geographic economy theory, this paper explains the nature, characteristics and their economic connection from the perspective of regional factor and non-regional factor matching by the model of increasing returns to scale and imperfect competition analysis. In addition, by means of fixed effect panel data and the GMM method, this paper also tests the dynamic relationship of factor mobility, allocation efficiency and regional economy agglomeration, aiming to make a theoretic interpretation, which conforms to reality, of regional agglomeration phenomenon in the background of economic integration.

\section{The Market Analysis and Model Testing of Economic Agglomeration}

Based on the agglomeration theory of factor mobility, it is possible to reveal the law of economic agglomeration among various types of economic activities in industry, between industry and region. In fact, from the perspective of microscopic, the agglomeration externalities produced by factor allocation efficiency are external to the enterprise; and from a perspective of macroscopic, the agglomeration externalities produced by factor selection efficiency spillover are is inherent. Therefore, enterprises which produce the same product can benefit from the layout together, and when the transportation cost of inter-regional product is lower than a certain value, the regional specialization of different regional factor endowments will be more efficient. The variables and data description:

It can be seen from the theoretical analysis that the regional economic agglomeration is the regional factor endowment advantage (RFS), non-tradable commodity scale (NTG), type commodity specialization degree (GED), market scale (MTD), technology spillover (TEI) and the market structure (MTS) and other variables as a function, namely(1): 
$A G L=f(R F S, N T G, G E D, M T D, T E I, M T S)$

At the same time, most scholars agree that foreign direct investment, human resources, transportation facilities, communication facilities and other factors are also important factors influencing the regional economic agglomeration. Therefore, to better reveal the relationship between factor mobility and allocation efficiency and regional economic agglomeration, the econometric equation of regional economic agglomeration problem in this paper adopts the following form (2):

$$
\begin{aligned}
\ln A G L= & \alpha_{0}+\alpha_{1} \ln M T S+\alpha_{2} \ln R F S+\beta_{1} \ln G E D+\beta_{2} \ln T E I+\beta_{3} \ln N T G+\lambda_{3} \ln M T D \\
& +\lambda_{4} \ln F D I+\lambda_{5} \ln H R+\lambda_{6} \ln V E H+\lambda_{7} \ln C M U+\varepsilon
\end{aligned}
$$

In this paper, 284 prefecture-level cities in China are used as sample source, and the data are from "China Urban Statistical Yearbook" and "China Regional Economic Statistical Yearbook". Among them: (1) Regional factor endowment advantage (RFS). (2) Size of non-tradable goods. (3) The degree of specialization (GED) of the type of commodity production. (4) Technology Spillovers (TEI). (5) The size of the market (MTD); (6) Market structure (MTS). (7) Human resource (HR)(8) Traffic facilities (VEH). (9) Communication infrastructure (CMU). (10) The level of regional economic agglomeration (AGL), the number of telephone calls per 100000 people in each city, the level of communication infrastructure construction in the region.

\section{GMM Estimation of Samples}

The estimating method adopted in this paper has a significant effect on the spillover of technology, the size of non-tradable goods, the size of market and the agglomeration of regional economy, because of the co-existence of variables. . For this reason, we use panel GMM (GMM) estimation to further analyze the intrinsic correlation of these variables. Considering the finite sample characteristic of the difference GMM is poor, this paper uses the generalized moment of the system to estimate the equation again (see Table 1).

It can be seen from Table 1 that the results of the estimation of factor mobility, allocation efficiency and regional economic agglomeration variables using the generalized moments are consistent with those of fixed effects panel data, but still has differences. Among them, the human resources for the regional economic agglomeration still has an important effect, and the significance is strong, which is clear in the equation $1,2,3,6,7$. and the results of the generalized moment estimation of the variables such as the degree of commodity specialization and the transport facilities are consistent with the previous fixed effect equation estimates. But it has a significant effect on the regional economic agglomeration, but the t-statistics of GMM has declined. Similarly, the impact of FDI on regional economic agglomeration is still significant, but the significance is declining. It should be noted that the GMM of the system is still insignificant, which is consistent with the analysis of fixed-effect panel data and further eliminates the influence of communication factors on regional economic agglomeration.

(1)The parameter estimation of the regional factor endowment advantage has increased in the majority of equations; the average parameter value is 0.21 , which indicates that regional factors play a decisive role in regional economic development. The nature of regional factor endowments in a given region determines the nature and characteristics of regional development.

(2)Equation 2, Equation 4, and Equation 6 reflect the parameters of the allocation efficiency variables for regional economic agglomeration. The parametric estimates of non-tradable goods are highly positively correlated and highly significant in the other equations, although they are not passed the test in Eq. 4. The estimates of the technical spillovers only fail to pass the test in Eq. 6, but also showed a high degree of positive correlation in the other significant equations. This shows that the regional and non-regional elements of the allocation efficiency are enough to form an endogenous economic concentration center. 
Table 1 GMM estimates of factor mobility, allocation efficiency and regional economic concentration

\begin{tabular}{|c|c|c|c|c|c|c|c|}
\hline variables & Eq. 1 & Eq. 2 & Eq. 3 & Eq. 4 & Eq. 5 & Eq. 6 & Eq. 7 \\
\hline $\operatorname{lnMTS}$ & $\begin{array}{l}0.1085 \\
\text { *** }\end{array}$ & $\begin{array}{l}0.1503 \\
* * *\end{array}$ & $\begin{array}{l}0.2001 * \\
* *\end{array}$ & $\begin{array}{l}0.1070 * \\
* *\end{array}$ & $\begin{array}{l}0.1880 * \\
* *\end{array}$ & $\begin{array}{l}0.2050 * \\
* *\end{array}$ & $\begin{array}{l}0.1740 * \\
* *\end{array}$ \\
\hline $\operatorname{lnRFS}$ & $\begin{array}{l}0.3705 \\
* * *\end{array}$ & - & & $\begin{array}{l}0.5584 * \\
* *\end{array}$ & $\begin{array}{l}0.2105^{*} \\
* *\end{array}$ & - & $\begin{array}{l}0.2400 * \\
* *\end{array}$ \\
\hline $\operatorname{lnGED}$ & - & $\begin{array}{l}0.0245 \\
* *\end{array}$ & - & $\begin{array}{l}0.0340 * \\
* *\end{array}$ & - & $\begin{array}{l}0.0177 * \\
* *\end{array}$ & $\begin{array}{l}0.0051 * \\
*\end{array}$ \\
\hline $\operatorname{lnNTG}$ & - & $\begin{array}{l}0.2010 \\
* * *\end{array}$ & - & $\begin{array}{l}0.0963 \\
(0.45)\end{array}$ & - & $\begin{array}{l}0.1273 * \\
* *\end{array}$ & $\begin{array}{l}0.0788^{*} \\
*\end{array}$ \\
\hline lnTEI & - & $\begin{array}{l}0.0161 \\
* * *\end{array}$ & - & $\begin{array}{l}0.0180 * \\
*\end{array}$ & - & $\begin{array}{l}0.0182 * \\
(0.74)\end{array}$ & $\begin{array}{l}0.0017 * \\
*\end{array}$ \\
\hline $\operatorname{lnMTD}$ & - & - & $\begin{array}{l}0.2111^{*} \\
* *\end{array}$ & - & $\begin{array}{l}0.1605 * \\
* *\end{array}$ & $\begin{array}{l}0.1647 * \\
* *\end{array}$ & $\begin{array}{l}0.0863 * \\
* *\end{array}$ \\
\hline lnFDI & $\begin{array}{l}0.0745 \\
* * *\end{array}$ & $\begin{array}{l}0.0021 \\
* *\end{array}$ & $\begin{array}{l}0.0032 * \\
* *\end{array}$ & $\begin{array}{l}0.0255^{*} \\
(0.84)\end{array}$ & $\begin{array}{l}0.0106^{*} \\
* *\end{array}$ & $\begin{array}{l}0.0324 * \\
(0.072)\end{array}$ & $\begin{array}{l}0.0272 * \\
(0.74)\end{array}$ \\
\hline $\operatorname{lnHR}$ & $\begin{array}{l}0.1583 \\
* * *\end{array}$ & $\begin{array}{l}0.1130 \\
* * *\end{array}$ & $\begin{array}{l}0.0800 * \\
* *\end{array}$ & $\begin{array}{l}0.0421 \\
(0.87)\end{array}$ & $\begin{array}{l}0.0310 \\
(0.70)\end{array}$ & $\begin{array}{l}0.0250 * \\
* \\
\end{array}$ & $\begin{array}{l}0.0017 * \\
*\end{array}$ \\
\hline $\operatorname{lnVEH}$ & $\begin{array}{l}0.0118 \\
* *\end{array}$ & $\begin{array}{l}0.0270 \\
(0.71)\end{array}$ & $\begin{array}{l}0.0654 \\
(0.08)\end{array}$ & $\begin{array}{l}0.0360 * \\
*\end{array}$ & $\begin{array}{l}0.0053 * \\
(0.61)\end{array}$ & $\begin{array}{l}0.0863 * \\
(0.70)\end{array}$ & $\begin{array}{l}0.0717 * \\
(0.56)\end{array}$ \\
\hline $\operatorname{lnCMU}$ & $\begin{array}{l}-0.0054 \\
(-0.15)\end{array}$ & $\begin{array}{l}-0.0536 \\
(-0.05)\end{array}$ & $\begin{array}{l}-0.0838 \\
* * *\end{array}$ & $\begin{array}{l}-0.0757 \\
(-0.34)\end{array}$ & $\begin{array}{l}-0.0307 \\
* * *\end{array}$ & $\begin{array}{l}-0.0202 \\
* * *\end{array}$ & $\begin{array}{l}-0.0481 \\
(-0.10)\end{array}$ \\
\hline Constant & $\begin{array}{l}0.031 * \\
*\end{array}$ & $\begin{array}{l}0.6646 \\
* *\end{array}$ & $\begin{array}{l}0.0056^{*} \\
(0.60)\end{array}$ & $\begin{array}{l}2.0080 * \\
* *\end{array}$ & $\begin{array}{l}1.0235 * \\
* *\end{array}$ & $\begin{array}{l}0.3084 * \\
*\end{array}$ & $\begin{array}{l}1.5767 * \\
* *\end{array}$ \\
\hline Wald test & $\begin{array}{l}130.34 \\
\lceil 0.000\rceil\end{array}$ & $\begin{array}{l}156.10 \\
{[0.000]}\end{array}$ & $\begin{array}{l}140.30 \\
\lceil 0.000]\end{array}$ & $\begin{array}{l}178.26 \\
\lceil 0.000]\end{array}$ & $\begin{array}{l}107.14 \\
{[0.000]}\end{array}$ & $\begin{array}{l}205.08 \\
\lceil 0.000]\end{array}$ & $\begin{array}{l}213.03 \\
\lceil 0.000]\end{array}$ \\
\hline $\begin{array}{c}\text { Sargan } \\
\text { test }\end{array}$ & $\begin{array}{l}47.58 \\
\lceil 0.151\rceil\end{array}$ & $\begin{array}{l}46.78 \\
{[0.210]}\end{array}$ & $\begin{array}{l}92.15 \\
\lceil 0.148\rceil\end{array}$ & $\begin{array}{l}74.47 \\
{[0.185]}\end{array}$ & $\begin{array}{l}71.58 \\
{[0.205]}\end{array}$ & $\begin{array}{l}75.22 \\
\lceil 0.164\rceil\end{array}$ & $\begin{array}{l}93.84 \\
{[0.121]}\end{array}$ \\
\hline $\begin{array}{c}\text { Hansen } \\
\text { test }\end{array}$ & $\begin{array}{l}19.24 \\
{[0.413]}\end{array}$ & $\begin{array}{l}25.87 \\
{[0.357]}\end{array}$ & $\begin{array}{l}32.00 \\
{[0.332]}\end{array}$ & $\begin{array}{l}40.08 \\
\lceil 0.312\rceil\end{array}$ & $\begin{array}{l}34.01 \\
{[0.326]}\end{array}$ & $\begin{array}{l}58.30 \\
{[0.082]} \\
\end{array}$ & $\begin{array}{l}73.04 \\
{[0.002]}\end{array}$ \\
\hline $\begin{array}{c}\text { Arellano- } \\
\text { Bond }\end{array}$ & $\begin{array}{l}-1.83 \\
{[0.041]}\end{array}$ & $\begin{array}{l}-2.72 \\
{[0.004]}\end{array}$ & $\begin{array}{l}-1.80 \\
{[0.046]}\end{array}$ & $\begin{array}{l}-1.61 \\
{[0.006]}\end{array}$ & $\begin{array}{l}-1.86 \\
{[0.038]}\end{array}$ & $\begin{array}{l}-2.41 \\
{[0.001]}\end{array}$ & $\begin{array}{l}-2.38 \\
{[0.002]}\end{array}$ \\
\hline $\begin{array}{l}\text { Arellano- } \\
\text { Bond }\end{array}$ & $\begin{array}{l}-0.11 \\
{[0.804]}\end{array}$ & $\begin{array}{l}0.01 \\
{[0.874]}\end{array}$ & $\begin{array}{l}0.27 \\
{[0.668]}\end{array}$ & $\begin{array}{l}-0.55 \\
{[0.465]}\end{array}$ & $\begin{array}{l}-0.11 \\
{[0.804]}\end{array}$ & $\begin{array}{l}0.02 \\
{[0.862]}\end{array}$ & $\begin{array}{l}-0.24 \\
{[0.704]}\end{array}$ \\
\hline
\end{tabular}

(3)The parameter estimation of market size shows positive correlation in each Equation, which indicates that a considerable part of China's regional economic development is due to the expansion of market demand. Because of the varying degrees of increasing returns to scale for the production of different types of products, the area devoted to the production of the type of product has a different size.

\section{The Conclusion and Enlightenment}

The study on the relationship between economic agglomeration, allocation efficiency and regional economic growth also provides theoretical support for the construction of the main functional areas in China. Although the main functional area theory is first proposed in China, there are no direct overseas research results. But, innovation is the result of logical criticism and logical deduction. It is precisely based on the reflection of disorderly development of real space; the main function area 
thought has just been condensed and put forward. The main functional area is a major theoretical innovation of China's regional economic development concept. Its essence is to break through the "no spatial dimension" analysis paradigm of traditional regional economic theory, and regional economic bearer (regional constraints such as resource constraints and environmental characteristics) into the theoretical analysis.

Therefore, only constructing a framework of heterogeneous spatial economic general equilibrium analysis based on monopolistic competition and increasing returns to scale can make a realistic theoretical judgment on the construction of main functional areas.

The possible way for China's realistic economy analysis is that we must construct a framework of heterogeneous spatial economic general equilibrium analysis with the characteristics of monopolistic competition and increasing returns to scale.

Because of the regional factor endowment conditions are different in regions and allocation efficiencies between the two types of elements; the fundamental objective of regional economic development is to improve the efficiency of various elements allocation according to their regional factor endowment conditions of sustainable development.

In the context of global economic integration, the choice of regional agglomeration core, according to local conditions, it is possible to lead to regional economic development, and ultimately the formation of complementary advantages, interactive cooperation between the regional development pattern, through the improvement of transportation infrastructure and public service level, the promotion of factors, technologies and products in the inter-regional movement.

\section{Acknowledgements}

National Social Science Fund Project: Cultural Identity of the "Belt and Road" Initiative Strategy and its Economic Influence (Project No: 16BJL099)

\section{References}

[1] Fujita M., P. Krugman and A.J.Venables, 1999. The Spatial Economy. Cities, Regions and International Trade. Cambridge: MIT Press.

[2] Krugman, P. R., 1991. Increasing Returns and Economic Geography. Journal of Political Economy, Vol.99, 483-499.

[3] Baldwin R., Martin P. and Ottaviano, 2001. "Global Income Divergence, Trade and Industrialization: the Geography of Growth Take-off." Journal of Economic Growth, Vol.6, pp.5-37.

[4] G. M. Grossman, E. Helpman. Innovation and Growth in the Global Economy [M]. Cambridge Massachusetts: MIT Press, 1991.

[5] Information on http://www.weld.labs.gov.cn

[6] Kenneth Waltz, 1996. "Evaluating Theories." The American Political Science Review, Vol. 91, pp. 913-917.

[7] Amanda Bullough, Maija Renko, Tamara Myatt. Danger Zone Entrepreneurs: The Importance of Resilience and Self - Efficacy for Entrepreneurial Intentions [J]. Entrepreneurship Theory and Practice. 2014 (3)

[8] Sterner, Thomas. Policy In strum environment a land Natural Resource Manage source for the Future. . 2003

[9] Bai Chongen, Du Yingjuan, Tao Zhigang,et al. Local protectionism and regional specialization: evidence from China's industries. Journal of International Economics. 2004

[10] Stavroula Laspita, Nicola Breugst, Stephan Heblich, Holger Patzelt. Intergenerational transmission of entrepreneurial intentions [J]. Journal of Business Venturing. 2011 (4) 